\title{
A multicenter case-control study on non-genetic risk factors in infants with congenital heart disease
}

Research article

Keywords:

Posted Date: December 1st, 2020

DOI: https://doi.org/10.21203/rs.2.16559/v2

License: (1) (i) This work is licensed under a Creative Commons Attribution 4.0 International License.

Read Full License 


\section{Abstract}

The authors have requested that this preprint be withdrawn due to erroneous posting.

\section{Full Text}

The authors have withdrawn this preprint from Research Square. 